\title{
Imidazole Alkaloids from the South China Sea Sponge Pericharax heteroraphis and Their Cytotoxic and Antiviral Activities
}

\author{
Kai-Kai Gong ${ }^{1,2,+}$, Xu-Li Tang ${ }^{3,+}$, Yi-Sheng Liu ${ }^{1}$, Ping-Lin Li ${ }^{2, *}$ and Guo-Qiang Li ${ }^{2, *}$ \\ 1 Department of Pharmacy, Binzhou Medical University Hospital, Yellow River Second Road 661, \\ Binzhou 256603, China; gongkaikai1005@163.com (K.-K.G.); byfy_lys@163.com (Y.-S.L.) \\ 2 Key Laboratory of Marine Drugs, Chinese Ministry of Education, School of Medicine and Pharmacy, \\ Ocean University of China, Yushan Road 5, Qingdao 266003, China \\ 3 College of Chemistry and Chemical Engineering, Ocean University of China, Songling Road 238, \\ Qingdao 266100, China; tangxuli@ouc.edu.cn \\ * Correspondence: lipinglin@ouc.edu.cn (P.-L.L.); liguoqiang@ouc.edu.cn (G.-Q.L.); \\ Tel.: +86-532-8203-2323 (G.-Q.L.); Fax: +86-532-8203-3054 (G.-Q.L.) \\ + These authors contributed equally to this work.
}

Academic Editor: Fernando Albericio

Received: 25 November 2015 ; Accepted: 21 January 2016 ; Published: 26 January 2016

\begin{abstract}
Marine sponges continue to serve as a rich source of alkaloids possessing interesting biological activities and often exhibiting unique structural frameworks. In the current study, chemical investigation on the marine sponge Pericharax heteroraphis collected from the South China Sea yielded one new imidazole alkaloid named naamidine J (1) along with four known ones (2-5). Their structures were established by extensive spectroscopic methods and comparison of their data with those of the related known compounds. All the isolates possessed a central 2-aminoimidazole ring, substituted by one or two functionalized benzyl groups in some combination of the $\mathrm{C} 4$ and $\mathrm{C} 5$ positions. The cytotoxicities against selected HL-60, HeLa, A549 and K562 tumor cell lines and anti-H1N1 (Influenza a virus (IAV)) activity for the isolates were evaluated. Compounds $\mathbf{1}$ and $\mathbf{2}$ exhibited cytotoxicities against the $\mathrm{K} 562$ cell line with $\mathrm{IC}_{50}$ values of 11.3 and $9.4 \mu \mathrm{M}$, respectively. Compound 5 exhibited weak anti-H1N1 (influenza a virus, IAV) activity with an inhibition ratio of $33 \%$.
\end{abstract}

Keywords: sponge; Pericharax heteroraphis; 2-aminoimidazole alkaloids; cytotoxicities; anti-H1N1 activity

\section{Introduction}

Marine sponges belonging to the Class Calcarea have been studied since the 1980s and have yielded a large number of bioactive alkaloids containing an imidazole heterocycle typically substituted with two benzylic fragments at the $\mathrm{C}-4, \mathrm{C}-5$, or $\mathrm{N}-3$ positions and at various oxidation states. In some cases the 2-amino moiety is further substituted with a hydantoin or a functionalized hydantoin derivative [1]. It was reported that this kind of alkaloid showed cytotoxic [2-4], antimicrobial $[5,6]$, and antifungal [7] properties, as well as leukotriene B4 receptor [8] and epidermal growth factor (EGF) receptor [9] antagonist activities. To discover new bioactive 2-aminoimidazole alkaloids, the marine sponge Pericharax heteroraphis (genus Pericharax family Leucettidae) drew our attention, as the UV characteristics of $\mathrm{MeOH}$ extracts showed the existence of 2-aminoimidazole alkaloids; in addition, its extracts were reported to have broad activity on cancer cell lines [10] and showed significant AChE-inhibitory activity [11]. In 2007, Ali et al. reported the isolation and antimicrobial activity of three 2-aminoimidazole alkaloids from Pericharax heteroraphis which is the only report about the chemical investigation of Pericharax heteroraphis [6]. Based on the above evidence, we aimed to 
investigate new cytotoxic compounds from Pericharax heteroraphis. The current sample was collected from the Yongxing Islands area of Hainan Province in the South China Sea. Combined HPLC analysis and bioassay-guided quick isolation of the imidazole alkaloid-rich portion of the MeOH extract of Pericharax heteroraphis yielded a new 2-aminoimidazole alkaloid (1), along with four known analogs (2-5) (Figure 1). Their cytotoxicities against four selected tumor cell lines and anti-H1N1 IAV (Influenza a virus) activities were evaluated. Herein, we describe the isolation, structural elucidation, and the cytotoxic and anti-IAV activities of the isolates.

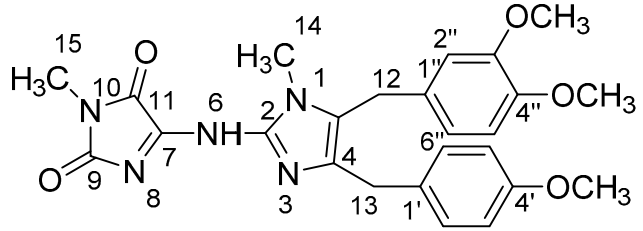

1<smiles>COc1ccc(Cc2nc(NC3=NC(=O)N(C)C3=O)n(C)c2Cc2ccc(OC)c(OC)c2O)cc1</smiles>

3<smiles>COc1ccc(Cc2nc(NC3=NC(=O)N(C)C3=O)n(C)c2Cc2ccc(OC)c(O)c2OC)cc1</smiles>

2<smiles>C[C@H]1OCOc2cc(/C=C3\N=C(N)N(C)C3=O)ccc2O1</smiles><smiles>COc1ccc(/C=C2\N=C(N)N(C)C2=O)cc1</smiles>

Figure 1. Structures of compounds 1-5.

\section{Results and Discussion}

\subsection{Structure Elucidation}

Naamidine J (1) was isolated as a yellow amorphous solid with a molecular formula of $\mathrm{C}_{25} \mathrm{H}_{28} \mathrm{~N}_{5} \mathrm{O}_{5}$ established by HR-ESI-MS, which showed a pseudo-molecular-ion peak at $\mathrm{m} / z 478.2091$ $\left([\mathrm{M}+\mathrm{H}]^{+} \mathrm{C}_{25} \mathrm{H}_{28} \mathrm{~N}_{5} \mathrm{O}_{5}{ }^{+}\right.$; cacld. 478.2085) (see Figure S2), requiring 15 degrees of unsaturation. Its ${ }^{13} \mathrm{C}-\mathrm{NMR}$ and DEPT spectra data exhibited a total of 25 resonances for five methyl, two methylene, and seven methine groups and eleven quarternary carbons. These data also revealed the presence of 11 double bonds $(7 \times \mathrm{CC} ; 2 \times \mathrm{CN} ; 2 \times \mathrm{CO})$; the ${ }^{1} \mathrm{H}-\mathrm{NMR}$ spectrum contained three singlets at $\delta_{\mathrm{H}} 3.77\left(3 \mathrm{H}, \mathrm{s}, 4^{\prime}-\mathrm{OCH}_{3}\right), 3.84\left(3 \mathrm{H}, \mathrm{s}, 3^{\prime \prime}-\mathrm{OCH}_{3}\right), 3.67\left(3 \mathrm{H}, \mathrm{s}, 4^{\prime \prime}-\mathrm{OCH}_{3}\right)$ for three methoxy groups, and two singlets at $\delta_{\mathrm{H}} 3.49\left(3 \mathrm{H}, \mathrm{s}, 14-\mathrm{NCH}_{3}\right), 3.17\left(3 \mathrm{H}, \mathrm{s}, 15-\mathrm{NCH}_{3}\right)$ indicating two $N$-methyl groups. In addition, the ${ }^{1} \mathrm{H}-\mathrm{NMR}$ spectrum of 1 showed a singlet aromatic signal at $\delta_{\mathrm{H}} 6.42\left(1 \mathrm{H}, \mathrm{s}, \mathrm{H}-2^{\prime \prime}\right)$, four doublet aromatic signals at $\delta_{\mathrm{H}} 7.13\left(2 \mathrm{H}, \mathrm{d}, J=8.4 \mathrm{~Hz}, \mathrm{H}-2^{\prime}, 6^{\prime}\right), 6.80\left(2 \mathrm{H}, \mathrm{d}, J=8.4 \mathrm{~Hz}, \mathrm{H}-3^{\prime}, 5^{\prime}\right), 6.74$ $\left(1 \mathrm{H}, \mathrm{d}, J=8.1 \mathrm{~Hz}, \mathrm{H}-5^{\prime \prime}\right), 6.54\left(1 \mathrm{H}, \mathrm{d}, J=8.1 \mathrm{~Hz}, \mathrm{H}-6^{\prime \prime}\right)$ consistent with the presence of two aromatic rings: one of them 1,3,4-substituted and the other 1,4-substituted (see Figures S3-S6). The NMR data strongly suggested compound 1 to be a 2-aminoimidazole alkaloid, almost identical to those of naamidine A [12] (Figure 2) except for the 1,3,4-substituted aromatic ring (Table 1). The 1,3,4-substituted aromatic ring (ring D) were readily indicated by HMBC cross-peaks, between $3^{\prime \prime}$-OMe $\left(\delta_{\mathrm{H}} 3.84\right)$ and $\mathrm{C}-3^{\prime \prime}$ $\left(\delta_{\mathrm{C}} 148.1\right)$, and between $4^{\prime \prime}$-OMe $\left(\delta_{\mathrm{H}} 3.67\right)$ and C-4 ${ }^{\prime \prime}\left(\delta_{\mathrm{C}} 149.5\right)$ (Table 2$)$ (see Figure S8). Since both $\mathrm{H}_{2}-12$ and $\mathrm{H}_{2}-13$ correlated to $\mathrm{C}-4$ and $\mathrm{C}-5$, the positions of the two functionalized benzyl groups were secured by NOESY correlations between $14-\mathrm{NCH}_{3}\left(\delta_{\mathrm{H}} 3.49\right)$ and $\mathrm{H}_{2}-12, \mathrm{H}-2^{\prime \prime}$, H-6 ${ }^{\prime \prime}$ (Figure 3) $[4,12]$ (see Figures S9-S11). Therefore, the structure of 1 was established. 
Four known analogs (Figure 1), naamidine H (2) [4], pyronaamidine (3) [13], leucettaamine B (4) [14], leucettamine C (5) [14], were also isolated and identified by comparison of their spectroscopic data with those reported in the literature.<smiles>COc1ccc(Cc2nc(NC3=NC(=O)N(C)C3=O)n(C)c2Cc2ccc(O)cc2)cc1</smiles>

Figure 2. Structure of naamidine A.

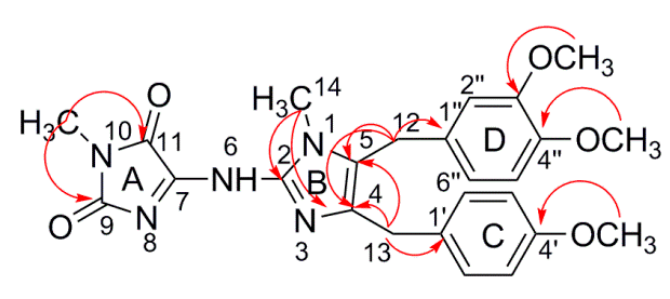

HMBC correlations

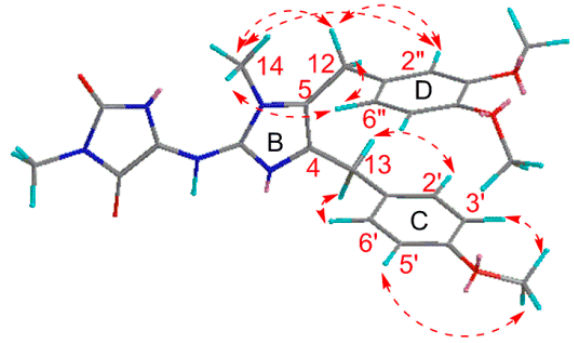

NOESY correlations

Figure 3. Selected key HMBC and NOESY correlations of compound $\mathbf{1 .}$

Table 1. The ${ }^{1} \mathrm{H}$ - and ${ }^{13} \mathrm{C}-\mathrm{NMR}$ data ${ }^{\mathrm{a}}$ for $\mathbf{1}^{\mathrm{b}}$ and naamidine $\mathrm{A}^{\mathrm{c}}$.

\begin{tabular}{|c|c|c|c|c|c|c|}
\hline \multirow{2}{*}{ Position } & \multicolumn{3}{|c|}{1} & \multicolumn{3}{|c|}{ Naamidine A } \\
\hline & $\delta_{\mathrm{H}}$, mult. $(J$ in $\mathrm{Hz})$ & & & $\delta_{\mathrm{H}}$, mult. $(J$ in $\mathrm{Hz})$ & & \\
\hline 1 & - & - & & - & - & \\
\hline 2 & - & 146.6 & (s) & - & 145.7 & (s) \\
\hline 3 & - & - & & - & - & \\
\hline 4 & - & 127.0 & (s) & - & 133.3 & (s) \\
\hline 5 & - & 129.7 & (s) & - & 126.9 & (s) \\
\hline 6 & - & - & & - & - & \\
\hline 7 & - & 144.7 & (s) & - & 148.4 & (s) \\
\hline 8 & - & - & (s) & - & - & (s) \\
\hline 9 & - & 155.5 & (s) & - & 157.3 & (s) \\
\hline 10 & - & - & & - & - & \\
\hline 11 & - & 162.3 & (s) & - & 162.5 & (s) \\
\hline 12 & $3.91(\mathrm{~s})$ & 29.2 & $(\mathrm{t})$ & $3.91(\mathrm{~s})$ & 27.7 & $(\mathrm{t})$ \\
\hline 13 & $3.89(\mathrm{~s})$ & 32.3 & $(\mathrm{t})$ & $3.93(\mathrm{~s})$ & 30.8 & $(t)$ \\
\hline 14 & $3.49(\mathrm{~s})$ & 30.1 & (q) & $3.39(\mathrm{~s})$ & 29.6 & (q) \\
\hline 15 & $3.17(\mathrm{~s})$ & 24.8 & (q) & $2.95(\mathrm{~s})$ & 24.4 & (q) \\
\hline $1^{\prime}$ & - & 131.7 & (s) & - & 131.9 & (s) \\
\hline $2^{\prime} 6^{\prime}$ & $7.13(\mathrm{~d} J=8.4 \mathrm{~Hz})$ & 129.5 & (d) & $7.15(\mathrm{~d} J=8.6 \mathrm{~Hz})$ & 129.5 & (d) \\
\hline $3^{\prime} 5^{\prime}$ & $6.80(\mathrm{~d} J=8.4 \mathrm{~Hz})$ & 114.2 & (d) & $6.81(\mathrm{~d} J=8.6 \mathrm{~Hz})$ & 113.9 & (d) \\
\hline $4^{\prime}$ & - & 158.3 & (s) & - & 157.8 & (s) \\
\hline $1^{\prime \prime}$ & - & 127.0 & (s) & - & 127.9 & (s) \\
\hline $2^{\prime \prime}$ & $6.42(\mathrm{~s})$ & 111.2 & (d) & $6.84(\mathrm{~d} J=8.6 \mathrm{~Hz})$ & 129.1 & (d) \\
\hline $3^{\prime \prime}$ & - & 148.1 & (s) & $6.63(\mathrm{~d} J=8.6 \mathrm{~Hz})$ & 115.5 & (d) \\
\hline $4^{\prime \prime}$ & - & 149.5 & (s) & - & 156.0 & (s) \\
\hline $5^{\prime \prime}$ & $6.74(\mathrm{~d} J=8.1 \mathrm{~Hz})$ & 111.5 & (d) & $6.63(\mathrm{~d} J=8.6 \mathrm{~Hz})$ & 115.5 & (d) \\
\hline $6^{\prime \prime}$ & $6.54(\mathrm{~d} J=8.1 \mathrm{~Hz})$ & 120.1 & (d) & $6.84(\mathrm{~d} J=8.6 \mathrm{~Hz})$ & 129.1 & (d) \\
\hline $4^{\prime} \mathrm{OCH} 3$ & $3.77(\mathrm{~s})$ & 55.3 & (q) & $3.69(\mathrm{~s})$ & 55.1 & (q) \\
\hline $3^{\prime \prime} \mathrm{OCH} 3$ & $3.84(\mathrm{~s})$ & 55.9 & (q) & - & - & (q) \\
\hline $4^{\prime \prime} \mathrm{OCH} 3$ & $3.67(\mathrm{~s})$ & 55.7 & (q) & - & - & (q) \\
\hline
\end{tabular}

${ }^{\text {a }}$ Measured at $500 \mathrm{MHz}\left({ }^{1} \mathrm{H}\right)$ and $125 \mathrm{MHz}\left({ }^{13} \mathrm{C}\right) \cdot{ }^{\mathrm{b}}$ Measured in $\mathrm{CDCl}_{3} \cdot{ }^{\mathrm{c}}$ Measured in $\mathrm{CDCl}_{3}+\mathrm{CD}_{3} \mathrm{OD}$. 
Table 2. NMR data for compound $\mathbf{1}$ (Recorded in $\left.\mathrm{CDCl}_{3}\right)^{\mathrm{a}}$.

\begin{tabular}{|c|c|c|c|c|c|}
\hline Position & $\delta_{\mathrm{H}}$, mult. $(J$ in $\mathrm{Hz})$ & $\delta_{C}$ & & $\mathrm{HMBC}(\mathrm{H}$ to $\mathrm{C})$ & NOESY \\
\hline 1 & - & - & & & \\
\hline 2 & - & 146.6 & (s) & & \\
\hline 3 & - & - & & & \\
\hline 4 & - & 127.0 & (s) & & \\
\hline 5 & - & 129.7 & (s) & & \\
\hline 6 & - & - & & & \\
\hline 7 & - & 144.7 & (s) & & \\
\hline 8 & - & - & (s) & & \\
\hline 9 & - & 155.5 & (s) & & \\
\hline 10 & - & - & & & \\
\hline 11 & - & 162.3 & (s) & & \\
\hline 12 & $3.91(\mathrm{~s})$ & 29.2 & $(\mathrm{t})$ & $C-1^{\prime \prime}, 2^{\prime \prime}, 6^{\prime \prime}, 4,5$ & $\mathrm{H}-2^{\prime \prime}, 6^{\prime \prime}$ \\
\hline 13 & $3.89(\mathrm{~s})$ & 32.3 & $(t)$ & $\mathrm{C}-1^{\prime}, 2^{\prime}, 6^{\prime}, 4,5$ & $\mathrm{H}-2^{\prime}, 6^{\prime}$ \\
\hline 14 & $3.49(\mathrm{~s})$ & 30.1 & (q) & C $-2,5$ & $\mathrm{H}-12,2^{\prime \prime}, 6^{\prime \prime}$ \\
\hline 15 & $3.17(\mathrm{~s})$ & 24.8 & (q) & C-9, 11 & \\
\hline $1^{\prime}$ & - & 131.7 & & & \\
\hline $2^{\prime} 6^{\prime}$ & $7.13(\mathrm{~d} J=8.4 \mathrm{~Hz})$ & 129.5 & (d) & $C-1^{\prime}, 4^{\prime}, 13$ & \\
\hline $3^{\prime} 5^{\prime}$ & $6.80(\mathrm{~d} J=8.4 \mathrm{~Hz})$ & 114.2 & (d) & $C-1^{\prime}, 4^{\prime}$ & \\
\hline $4^{\prime}$ & - & 158.3 & (s) & & \\
\hline $1^{\prime \prime}$ & - & 127.0 & (s) & & \\
\hline $2^{\prime \prime}$ & $6.42(\mathrm{~s})$ & 111.2 & (d) & $C-12,6^{\prime \prime}, 4^{\prime \prime}$ & \\
\hline $3^{\prime \prime}$ & - & 148.1 & (s) & & \\
\hline $4^{\prime \prime}$ & - & 149.5 & (s) & & \\
\hline $5^{\prime \prime}$ & $6.74(\mathrm{~d} J=8.1 \mathrm{~Hz})$ & 111.5 & (d) & $C-4^{\prime \prime}$ & \\
\hline $6^{\prime \prime}$ & $6.54(\mathrm{~d} J=8.1 \mathrm{~Hz})$ & 120.1 & (d) & $C-13,5^{\prime \prime}, 4^{\prime \prime}$ & \\
\hline $4^{\prime} \mathrm{OCH} 3$ & $3.77(\mathrm{~s})$ & 55.3 & (q) & $C-4^{\prime}$ & $\mathrm{H}-3^{\prime}, 5^{\prime}$ \\
\hline $3^{\prime \prime} \mathrm{OCH} 3$ & $3.84(\mathrm{~s})$ & 55.9 & (q) & $C-3^{\prime \prime}$ & $\mathrm{H}-5^{\prime \prime}$ \\
\hline $4^{\prime \prime} \mathrm{OCH} 3$ & $3.67(\mathrm{~s})$ & 55.7 & (q) & $C-4^{\prime \prime}$ & $\mathrm{H}-2^{\prime \prime}$ \\
\hline
\end{tabular}

\subsection{Biological Evaluations}

The cytotoxicities for all the compounds (1-5) against four tumor cell lines (human leukemia, K562; human myeloid leukemia, HL-60; human cervical carcinoma, HeLa; human lung adenocarcinoma, A549) were evaluated in vitro by MTT (3-(4,5-dimethylthiazol-2-yl)2,5-diphenyl-2H-tetrazolium bromide) and SRB (Sulforhodamine B) methods (Table 3). Compounds $\mathbf{1}$ and $\mathbf{2}$ showed modest cytotoxicities against the $\mathrm{K} 562$ cell line, with $\mathrm{IC}_{50}$ values of 11.3 and $9.4 \mu \mathrm{M}$, respectively. Compound 2 exhibited weak inhibitory activities against the HeLa and A549 cell lines with $\mathrm{IC}_{50}$ values of 21.4 and $22.4 \mu \mathrm{M}$, respectively (see Table S1). It is certainly noteworthy that despite the close structural similarity of compounds $\mathbf{1 - 5}$, only compounds $\mathbf{1}$ and $\mathbf{2}$ were found to be cytotoxic.

Table 3. The $\mathrm{IC}_{50}$ values of the compounds 1-5 against four tumor cell lines.

\begin{tabular}{ccccc}
\hline \multirow{2}{*}{ Compounds } & \multicolumn{4}{c}{$\mathrm{IC}_{\mathbf{5 0}}(\boldsymbol{\mu M})$} \\
\cline { 2 - 5 } & $\mathbf{H e L a}^{\mathbf{a}}$ & $\mathbf{P 3 8 8}^{\mathbf{b}}$ & $\mathbf{A 5 4 9}^{\mathbf{a}}$ & $\mathbf{K 5 6 2}^{\mathbf{b}}$ \\
\hline $\mathbf{1}$ & NA & NA & NA & 11.3 \\
$\mathbf{2}$ & 21.4 & NA & 22.1 & 9.4 \\
$\mathbf{3}$ & NA & NA & NA & NA \\
$\mathbf{4}$ & NA & NA & NA & NA \\
$\mathbf{5}$ & NA & NA & NA & NA \\
ADM(Adriamycin) $^{c}$ & 0.2 & 0.02 & 0.6 & 0.2 \\
\hline
\end{tabular}

${ }^{a}$ By SRB method; ${ }^{b}$ By MTT method; ${ }^{c}$ Positive control; NA inactive. 
Antiviral activities of compounds 3-5 against H1N1 IAV were also evaluated by the cytopathic effects assays (CPE). Only compound 5 exhibited weak anti-H1N1 virus activity with an inhibition rate of 33\% (Ribavirin was used as a positive control with an inhibition rate of 65\%) (see Table S2). However, this is the first report of 2-aminoimidazole types of alkaloids having activity against a flu virus.

\section{Experimental Section}

\subsection{General Methods}

UV spectra were measured with a Beckman DU640 spectrophotometer (Beckman Coulter Inc., Brea, CA, USA). IR spectra were recorded on a Nicolet NEXUS 470 spectrophotometer (International Equipment Trading Ltd., Vernon Hills, IL, USA). NMR spectra were measured with Bruker 500 spectrometer (500 MHz for ${ }^{1} \mathrm{H}$ and $125 \mathrm{MHz}$ for ${ }^{13} \mathrm{C}$ ) (Bruker Daltonics Inc., Billerica, MA, USA) using TMS (tetramethylsilane) as internal standard and chemical shifts were referenced to residual non-deuterated solvent signals $\left(\mathrm{CDCl}_{3}: \delta_{\mathrm{H}} 7.26 \mathrm{ppm}, \delta_{\mathrm{C}} 77.16 \mathrm{ppm}\right)$. The melting points uncorrected were measured on an X-4 micro-scopic melting point apparatus (Shanghai Instrument Physical Optics Instrument Co. Ltd., Shanghai, China). HR-ESI-MS data were obtained on a Micromass Q-Tof Ultima GLOBAL GAA076 LC mass spectrometer on a Thermo Scientific LTQ orbitrap XL mass spectrometer (Thermo Fisher Scientific Inc., Waltham, MA, USA). HPLC isolation was achieved on a Waters 2695 and Agilent 1100 instruments using semi-preparative HPLC columns (YMC-packed C18 and C8, $5 \mu \mathrm{m}$, $250 \times 10 \mathrm{~mm})($ YMC Co. Ltd., Kyoto, Japan). Medium pressure liquid chromatograph (MPLC) was performed on a Bonna Agela LC-10F instrument using ODS (octa decylsilyl silicion) column (ODS, $50 \mu \mathrm{m}, 310 \times 15 \mathrm{~mm}$ ) (Bonna-Agela Technologies Inc., Tianjin, China). Silica-gel (200-300 mesh, 300-400 mesh, Qingdao Marine Chemical Factory, Qingdao, Shandong, China) and ODS silica-gel (50 $\mu \mathrm{m}$, Merck, Darmstadt, Germany) were used for column chromatography (CC). TLC was carried out with glass precoated silica gel $\mathrm{GF}_{254}$ plates (Qingdao Marine Chemical Factory, Qingdao, Shandong, China). Spots were visualized under UV light or by spraying with $10 \% \mathrm{H}_{2} \mathrm{SO}_{4}$ in $\mathrm{EtOH}-\mathrm{H}_{2} \mathrm{O}(95: 5, v / v)$ followed by heating.

\subsection{Animal Material}

The marine sponge Pericharax heteroraphis was collected from the South Sea (Yongxing Islands area) at a depth of $12 \mathrm{~m}\left(16^{\circ} 55^{\prime} 32^{\prime \prime} \mathrm{N}, 112^{\circ} 20^{\prime} 32^{\prime \prime} \mathrm{E}\right)$ (see Figure S1), and was frozen immediately after collection. The specimen was identified by Dr. Nicole J. de Voogd (National Museum of Natural History, Leiden, the Netherlands). The voucher specimen (NO. XS 2012-28) was deposited at State Key Laboratory of Marine Drugs, Ocean University of China, Qingdao, Shandong, China.

\subsection{Extraction and Isolation}

The frozen sample of Pericharax heteroraphis $(2.8 \mathrm{~kg}$, wet weight) was homogenized and then extracted with $\mathrm{MeOH}$ three times ( $5 \mathrm{~L} \times 3$, each, three days) at room temperature, and the solution was evaporated in vacuum to yield a crude extract $(36.2 \mathrm{~g})$ which was subjected to column chromatography (CC) on silica gel using petroleum ether/acetone (from 100:1 to 1:2, v/v) as eluent. In the process of eluting, many yellow substances $(6.7 \mathrm{~g})$ were obtained and analyzed on HPLC. According to the literature and UV characteristic (Figure 4), the yellow substances could be preliminary ascertained as imidazole alkaloids thus for the further separation. Part of yellow substances ( $1.3 \mathrm{~g})$ were subjected to medium pressure liquid chromatograph (MPLC) eluting with a gradient increasing $\mathrm{MeOH}$ in $\mathrm{H}_{2} \mathrm{O}$ to afford three main peaks (P. 1-P. 3) which were collected separately. P. 1 (12.3 mg) showed one peak on C18 and C8 column at several modified gradients but was not pure in the ${ }^{1} \mathrm{H}-\mathrm{NMR}$ spectrum thus for further purified on chiral column (CHIRALPAK ${ }^{\circledR} \mathrm{IC}: 5 \mu \mathrm{m} ; 100 \% \mathrm{MeOH} ; 0.7 \mathrm{~mL} / \mathrm{min}$ ) to yield compounds 4 (3.5 mg) and 5 (4.3 mg). P. 2 (40 mg) was further separated by HPLC (YMC-Pack ODS C 8 $65 \% \mathrm{CH}_{3} \mathrm{CN}$ in $\mathrm{H}_{2} \mathrm{O}$ with $\left.1 \% \mathrm{HCOOH}_{1} 1.5 \mathrm{~mL} / \mathrm{min}\right)$ to yield compound 3 (30 mg). P. 3 (24 mg) was further purified by HPLC (ODS. C8; 64\% $\mathrm{CH}_{3} \mathrm{CN}$ in $\mathrm{H}_{2} \mathrm{O}$ ) to yield compounds 1 (5.3 mg) and 2 (8 mg). 

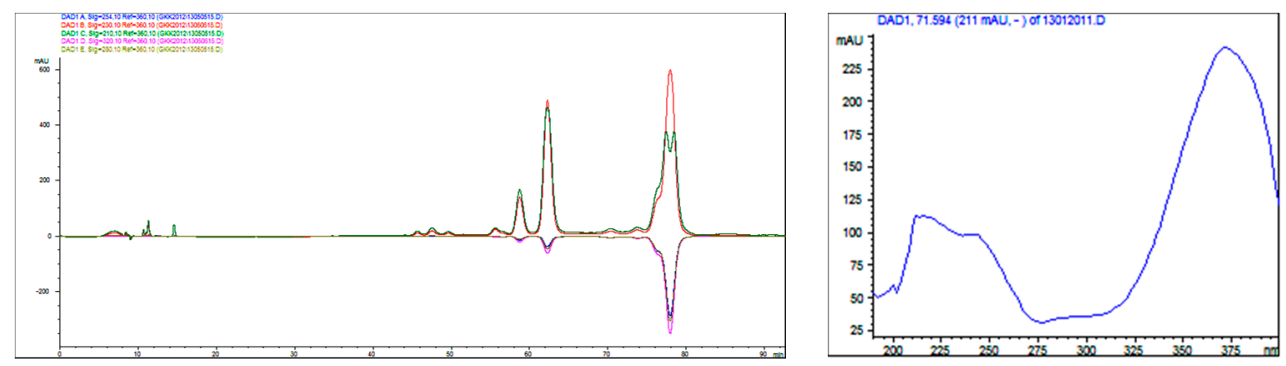

Figure 4. The HPLC and UV chromatograms of 2-aminoimidazole alkaloids.

Compound 1: 4-\{[5-(3,4-dimethoxybenzyl)-4-(4-methoxybenzyl)-1-methyl-1H-imidazol-2-yl]amino\}-1methyl-1H-imidazole-2,5-dione. Yellow amorphous solid; melting point (m.p.): $102-104{ }^{\circ} \mathrm{C}$; UV (MeOH): $\lambda_{\max }(\log \varepsilon) 225$ (4.27), 275 (3.77), 392 (3.97) nm; IR (KBr): 3427, 2960, 2873, 1731, 1710, 1377, 1250, 1068, $1025 \mathrm{~cm}^{-1} ;{ }^{1} \mathrm{H}$ and ${ }^{13} \mathrm{C}-\mathrm{NMR}$ : see Table 1; HR-ESI-MS: $\mathrm{m} / z 478.2091[\mathrm{M}+\mathrm{H}]^{+}$(calcd. for $\left.\mathrm{C}_{25} \mathrm{H}_{28} \mathrm{O}_{5} \mathrm{~N}_{5}{ }^{+}, 478.2085\right) ; 500.1906[\mathrm{M}+\mathrm{Na}]^{+}$(calcd. for $\mathrm{C}_{25} \mathrm{H}_{27} \mathrm{NaO}_{5} \mathrm{~N}_{5}{ }^{+}, 500.1904$ ).

\subsection{Cytotoxic Assay}

In vitro cytotoxicities were determined by MTT [3-(4,5-dimethylthiazol-2-yl)-2, 5-diphenyltetrazolium bromide]colorimetric assay against K562 (human leukemia cells) and HL-60 (human myeloid leukemia cells), SRB (Sulforhodamine B) assay against HeLa (human cervical carcinoma cells) and A549 (human lung adenocarcinoma cells). All the cell lines were purchased from Shanghai Institute of Cell Biology (Shanghai, China). Cytotoxic data (Table 3) for compounds 1-5 were obtained on the basis of five concentrations with three replications. Adriamycin (doxorubicin, ADM) was used as a positive control, and $\mathrm{IC}_{50}$ values $>50 \mu \mathrm{M}$ were considered to be inactive in cytotoxic assays.

In the MTT assay [15], the cells were cultured in RPMI-1640 supplemented with 10\% FBS under a humidified atmosphere of $5 \% \mathrm{CO}_{2}$ and $95 \%$ air at $37^{\circ} \mathrm{C}$. Those cell suspensions $(200 \mu \mathrm{L})$ at a density of $5 \times 10^{4}$ cell $\mathrm{mL}^{-1}$ were plated in 96-well microtiter plates and incubated for $24 \mathrm{~h}$ at the above conditions. The test compound solution ( $2 \mu \mathrm{L}$ in DMSO) at different concentrations in triplicate was added to each well and was further incubated for $72 \mathrm{~h}$ under the same conditions. $20 \mu \mathrm{L}$ of the MTT solution ( $5 \mathrm{mg} / \mathrm{mL}$ in IPMI-1640 medium) was then added to each well and incubated for $4 \mathrm{~h}$. The old medium containing MTT $(150 \mu \mathrm{L})$ was then gently replaced by DMSO and vibrated to dissolve any formazan [1-(4-Iodophenyl)-5-(4-nitrophenyl)-3-phenylformazan] crystals formed. The optical density of the solution was measured on a Spectra Max Plus plate reader at $570 \mathrm{~nm}$. The $\mathrm{IC}_{50}$ value of each compound was calculated by Reed and Muench's method.

In the SRB assay [16], $200 \mu \mathrm{L}$ of the cell suspensions were plated in 96-well plates at a density of $2 \times 10^{5}$ cell $\mathrm{mL}^{-1}$. Then $2 \mu \mathrm{L}$ of the test solutions (in $\mathrm{MeOH}$ ) was added to each well, and the culture was further incubated for $24 \mathrm{~h}$. The cells were fixed with $12 \%$ trichloroacetic acid, and the cell layer was stained with $0.4 \%$ SRB. The absorbance of the SRB solution was measured at $515 \mathrm{~nm}$. Dose-response curves were generated, and the $\mathrm{IC}_{50}$ values (the concentration of compound required to inhibit cell proliferation by $50 \%$ ) were calculated from the linear portion of log dose-response curves.

\subsection{Anti-H1N1 Virus Assay}

The antiviral activity against H1N1 was evaluated by the cytopathic effects assays (CPE) [17]. Confluent MDCK (Madin-Daby canine kidney) cell monolayers were firstly incubated with influenza virus (A/Puerto Rico/8/34 (H1N1), PR/8) at $37^{\circ} \mathrm{C}$ for $1 \mathrm{~h}$. After removing the virus dilution, cells were maintained in infecting media (RPMI 1640, $4 \mu \mathrm{g} / \mathrm{mL}$ of trypsin) containing different concentrations of test compounds at $37{ }^{\circ} \mathrm{C}$. After $48 \mathrm{~h}$ incubation at $37^{\circ} \mathrm{C}$, cells were fixed with $100 \mu \mathrm{L}$ of $4 \%$ formaldehyde for $20 \mathrm{~min}$ at room temperature. After removal of the formaldehyde, the cells were stained with $0.1 \%$ crystal violet for $30 \mathrm{~min}$. The plates were washed and dried, and the intensity of 
crystal violet staining for each well was measured in a microplate reader (Bio-Rad, Hercules, CA, USA) at $570 \mathrm{~nm}$. The $\mathrm{IC}_{50}$ was calculated as the compound concentration required inhibiting CPE production at $48 \mathrm{~h}$ post-infection by 50\%. Ribavirin (LuKang Cisen, Jining, China) was used as positive control, and compounds with an inhibition rate of $>70 \%,>50 \%$, and $<30 \%$ at $50 \mu \mathrm{g} / \mathrm{mL}$ were respectively regarded as having strong, moderate, and weak activities.

\section{Conclusions}

The present work offered one new member of 2-aminoimidazole alkaloids and the first isolation of compounds 1, 2, 3 and 5 from the genus Pericharax, and firstly reported anti-H1N1 virus activities of this type of alkaloid. Compounds $\mathbf{1}$ and $\mathbf{2}$ showed cytotoxic activity against the K562 cell line, suggesting that they might have the potential to be developed as antitumor agents. It was reported that the extract of Pericharax heteroraphis showed significant anti-AChE-inhibitory activity, and continuing investigation of the anti-AChE-inhibitory activity of the isolates is worthwhile.

Supplementary Materials: Supplementary materials can be accessed at: http://www.mdpi.com/1420-3049/ 21/2/150/s1.

Acknowledgments: This work was supported by the National Natural Science Foundation of China (41376142; 21572210; u1406402-1). Special thanks are given to Li, J. and Wang, W. (Key Laboratory of Marine Drugs, Chinese Ministry of Education, School of Medicine and Pharmacy, Ocean University of China, Qingdao, China) for the cytotoxicity and antivirus tests, and to Nicole J. de Voogd (National Museum of Natural History, Leiden, The Netherlands) for the marine sponge species identification.

Author Contributions: K.-K. Gong and X.-L. Tang contribute to extraction, isolation and identification and manuscript preparation; Y.-S. Liu mainly took part in the extraction and isolation; P.-L. Li contribute to structure elucidation; G.-Q. Li was the project leader organizing and guiding the experiments and manuscript writing.

Conflicts of Interest: The authors declare no conflict of interest.

\section{References}

1. Koswatta, P.B.; Lovely, C.J. Structure and Synthesis of 2-aminoimidazole Alkaloids from Leucetta and Clathrina Sponges. Nat. Prod. Rep. 2011, 28, 511-528. [CrossRef] [PubMed]

2. Gross, H.; Kehraus, S.; König, G.M.; Woerheide, G.; Wright, A.D. New and Biologically Active Imidazole Alkaloids from Two Sponges of the Genus Leucetta. J. Nat. Prod. 2002, 65, 1190-1193. [CrossRef] [PubMed]

3. Plubrukarn, A.; Smith, D.W.; Cramer, R.E.; Davidson, B.S. (2E,9E)-Pyronaamidine 9-(N-Methylimine), a New Imidazole Alkaloid from the Northern Mariana Islands Sponge Leucetta sp. cf. chagosensis. J. Nat. Prod. 1997, 60, 712-715. [CrossRef] [PubMed]

4. Tsukamoto, S.; Kawabata, T.; Kato, H.; Ohta, T.; Rotinsulu, H.; Mangindaan, R.E.P.; van Soest, R.W.M.; Ukai, K.; Kobayashi, H.; Namikoshi, M. Naamidines H and I, Cytotoxic Imidazole Alkaloids from the Indonesian Marine Sponge Leucetta chagosensis. J. Nat. Prod. 2007, 70, 1658-1660. [CrossRef] [PubMed]

5. Ralifo, P.; Crews, P. A New Structural Theme in the Imidazole-Containing Alkaloids from a Calcareous Leucetta Sponge. J. Org. Chem. 2004, 69, 9025-9029. [CrossRef] [PubMed]

6. Ali, A.A.; Hassanean, H.A.; Elkhayat, E.S.; Edrada, R.A.; Ebel, R.; Proksch, P. Imidazole Alkaloids from the Indopacific Sponge Pericharax heteroraphis. Bull. Pharm. Sci. 2007, 30, 149-157.

7. Fu, X.; Schmitz, F.J.; Tanner, R.S.; Kelly-Borges, M. New Imidazole Alkaloids and Zinc Complexes from the Micronesian Sponge Leucetta cf. chagosensis. J. Nat. Prod. 1998, 61, 384-386.

8. Chan, G.W.; Mong, S.; Hemling, M.E.; Freyer, A.J.; Offen, P.H.; Debrosse, C.W.; Sarau, H.M.; Westley, J.W. New Leukotriene B, Receptor Antagonist: Leucettamine A and Related Imidazole Alkaloids from the Marine Sponge Leucetta microraphis. J. Nat. Prod. 1993, 56, 116-121. [CrossRef] [PubMed]

9. Copp, B.R.; Fairchild, C.R.; Cornell, L.; Casazza, A.M.; Robinson, S.; Ireland, C.M. Naamidine A Is an Antagonist of the Epidermal Growth Factor Receptor and an in Vivo Active Antitumor Agent. J. Med. Chem. 1998, 41, 3909-3911. [CrossRef] [PubMed] 
10. Beedessee, G.; Ramanjooloo, A.; Aubert, G.; Eloyc, L.; Surnam-Boodhuna, R.; van Soest, R.W.M.; Cresteil, T.; Marie, D.E.P. Cytotoxic activities of hexane, ethyl acetate and butanol extracts of marine sponges from Mauritian Waters on human cancer cell lines. Environ. Toxicol. Pharmacol. 2012, 34, 397-408. [CrossRef] [PubMed]

11. Girish, B.; Avin, R.; Rashmee, S.B.; van Soest, R.W.M.; Marie, D.E.P. Acetylcholinesterase-Inhibitory Activities of the Extracts from Sponges Collected in Mauritius Waters. Chem. Biodivers. 2013, 10, 442-451.

12. Carmely, S.; Kashman, Y. Naamines and naamidines, novel imidazole alkaloids from the calcareous sponge Leucetta chagosensis. Tetrahedron Lett. 1987, 28, 3003-3006. [CrossRef]

13. Akee, R.K.; Carroll, T.R.; Yoshida, W.Y.; Scheuer, P.J. Two Imidazole Alkaloids from a Sponge. J. Org. Chem. 1990, 55, 1944-1946. [CrossRef]

14. Crews, P.; Clark, D.P.; Tenney, K. Variation in the Alkaloids among Indo-Pacific Leucetta Sponges. J. Nat. Prod. 2003, 66, 177-182. [CrossRef] [PubMed]

15. Alley, M.C.; Scudiere, D.A.; Monks, A.; Hursey, M.L.; Czerwinski, M.J.; Fine, D.L.; Abbott, B.J.; Mayo, J.G.; Shoemaker, R.H.; Boyd, M.R. Feasibility of Drug Screening with Panels of Human Tumor Cell Lines Using a Microculture Tetrazolium Assay. Cancer. Res. 1988, 48, 589-601. [PubMed]

16. Skehan, P.; Storeng, R.; Scudiero, D.; Monks, A.; McMahon, J.; Vistica, D.; Warren, J.T.; Bokesch, H.; Kenney, S.; Boyd, M.R. New Colorimetric Cytotoxicity Assay for Anticancer-Drug Screening. J. Natl. Cancer Inst. 1990, 82, 1107-1112. [CrossRef] [PubMed]

17. Wang, W.; Zhang, P.; Yu, G.L.; Li, C.X.; Hao, C.; Qi, X.; Zhang, L.J.; Guan, H.S. Preparation and Anti-Influenza A Virus Activity of k-Carrageenan Oligosaccharide and Its Sulphated Derivatives. Food Chem. 2012, 133, 880-888. [CrossRef]

Sample Availability: Samples of the compounds 1-5 are available from the authors.

(C) 2016 by the authors; licensee MDPI, Basel, Switzerland. This article is an open access article distributed under the terms and conditions of the Creative Commons by Attribution (CC-BY) license (http:/ / creativecommons.org/licenses/by/4.0/). 